\title{
ETIKA PRODUKSI DALAM PANDANGAN MAQASID SYARI'AH
}

\author{
Agus Alimuddin \\ Universitas Islam Indonesia \\ Email: agusalimuddin13@gmail.com
}

\begin{abstract}
Production is the process of creating goods or services that are done by humans to fulfill the needs of consumers, production activities if not pay attention to the value of Islamic business ethics will give birth to exploitation of resources. Production that is accompanied by the value of Islamic business ethics in the estuary will eventually maintain the value of fairness and morality as a means of limitation to fallah (welfare). In this study using a literature review with a descriptive-analysis method, the research library is to read the literary work related to the problem that is being researched, the study tried to analyze the ethical production in sharia maqasid views, according to Abu Ishaq al-Syatibi, maqasid is divided into three parts Dharuriyat, Hajiyyat, and Tahsiniyat. Dharuriyat as a maqasid the primary needs must be fulfilled or as a primary necessity. If this part of the need can not be fulfilled, can lead to human welfare nowadays and in the hereafter will not be realized, production activities in order to create benefits for people, the benefit can be created if it can Maintain and maintain all essential elements, namely; Religion, soul, reason, descent, and treasure.
\end{abstract}

Keywords: Business Ethics, Maqasid Syariah, Production.

\section{A. Pendahuluan}

Kegiatan produksi merupakan proses penciptaan yang sudah ada di muka bumi ketika manusia turut hadir di dunia ini. Produksi menjadi bagian terpenting bagi kehidupan manusia dan keberlangsungan peradaban di dunia ini. Untuk menciptakan keberlangsungan manusia dan alam, manusia berkewajiban menjadi pemimpin di dunia sesuai dengan ketetapan Allah SWT. Bumi sebagai lapangan pencarian, dan manusia mengelola seluruh sumber daya yang ada di bumi untuk dimanfaatkan sebagai kebutuhan manusia. ${ }^{1}$

Produksi merupakan proses yang dilakukan manusia untuk menciptakan barang atau jasa, yang diciptakan untuk memenuhi kebutuhan konsumen. Secara garis besar, produksi ialah proses mentranformasikan bahan dasar menjadi bahan siap dipakai. ${ }^{2}$ Jadi, tanpa adanya proses produksi konsumen tidak akan bisa memenuhi kebutuhannya baik dalam bentuk barang ataupun jasa.

Tidak bisa dibiarkan pengabaian tentang konsep produksi konvensional pada sistem nilai telah mereduksi kualitas hidup saat ini. Masalah sebenarnya terletak pada tata cara dan sistem yang secara massif jika dibiarkan akan mengalami perkembangan, yakni faktor produksi tanpa mempertimbangkan etika dalam produksi. Pada ekonomi konvensional permasalahann yang timbul karena kelangkaan barang atau jasa juga keterbatasan produksi karena kemampuan, maka kegiatan produksi dihadapkan pada persoalan dalam memaksimal sumber daya yang tersedia untuk memenuhi kebutuhan manusia yang semakin hari semakin kompleks dalam pemenuhan permintaan. Selain

1Adhiwarman .A. Karim, Ekonomi Mikro Islami (Jakarta: Raja Grafindo Persada, 2007), h. 102.

2Vina Sri Yuniarti, Ekonomi Mikro Syariah (Bandung: Pustaka Setia, 2016), h. 121. 
dituntut penggunaan sumber daya seefisien mungkin, produsen juga mengabaikan etika bisnis agar produksi dapat dilakukan secara bebas.

Dalam produksi tidak menggunakan etika, maka akan melahirkan eksploitasi pada sumber daya, sistem ekonomi kapitalisme dalam pandangan budaya materialnya peningkatan kekayaan dipandang sebagai tujuan utama dan cita-cita dasar. ${ }^{3}$ Untuk memenuhi kebutuhan manusia maka peningkatan produksi dan eksploitasi maksimal adalah solusi pemecahannya. ${ }^{4}$

Dalam produksi, untuk mengelola sumber daya tentu berdasarkan pada nilai-nilai islam yang bertujuan untuk mewujudkan kemashlahatan yang maksimal bagi konsumen atau bagi seluruh manusia. Dengan kemashlahatan yang maka maka akan tercipta kemuliaan kehidupan manusia di dunia dan akhirat dengan kebahagiaan hakiki yang menjadi orientasi akhir dari aktifitas perekonomian juga sebagai tujuan bagi kehidupan manusia. ${ }^{5}$

Pada dasarnya dalam proses mengelola sumber daya, aktivitas produksi harus diiringi dengan nilai-nilai keislaman, yang pada muara akhirnya dapat menghadirkan kesejahteraan yang akan terlihat dari material dan etika. ${ }^{6}$ Kegiatan produksi bukan sekadar memprioritaskan keuntungan material saja, ada nilai harmonisasi antara kebutuhan material dan moral, sehingga tugas manusia sebagai pemimpin di bumi bisa mensejahterakan bumi secara baik dengan tidak merusak alam dan mengeksploitasi melebihi batasan kebutuhan. ${ }^{7}$

\section{B. Metode}

Penelitian memerlukan metode untuk memecahkan permaslahan, metode penelitian diharapkan dapat mencapai hasil penelitian yang relevan. Penggunaan metode merupakan hal yang terpenting, metode sebagai cara kerja yang mampu menguraikan permasalahan yang timbul dalam penelitian dengan menggunakan teknik atau cara tertentu untuk mencapai suatu tujuan. Adapun dalam penelitian ini menggunakan kajian pustaka dengan metode deskriptifanalisis, penelitian pustaka yakni dengan mengamati permasalahan yang diteliti lalu menganailisis dengan cara menghubungkan permasalahan dengan literatur yang sesuai kebutuhan baik secara konsep maupun teori yang tepat. Penelitian ini bertujuan untuk melahirkan konsep yang senantiasa dijadikan payung etika yang dianut dalam kegiatan produksi dengan memperhatikan nilai kemaslahatan.

\section{Pembahasan}

\section{C.1. Etika Bisnis}

Kata "Etik" yakni "ethos" mempunyai pengertian kebiasaan atau adat, perasaan, watak, sikap, cara berfikir, padang rumput, tempat tinggal yang biasa, dan kandang, kata ini alanya dari bahasa Yunani. ${ }^{8}$ Sehingga dalam hal ini etika

${ }^{3}$ Muhammad Baqir Ash Shadr, Buku Induk Ekonomi Islam: Iqtishaduna, alih bahasa Yudi, vol. 1 (Jakarta: Zahra, 2008), h. 422.

${ }^{4}$ Ibid., h.423.

5Pusat Pengkajian dan Pengembangan Ekonomi Islam (P3EI) UII, Ekonomi Islam (Jakarta: RajaGrafindo Persada, 2008), h. 264.

6Fahrur Ulum, "Telaah Kritis Atas Pemikiran Ekonomi Islam Abdul Mannan," al-Qanun,vol 02 No. 2 (Desember, 2009), h. 448.

${ }^{7}$ Adhiwarman .A. Karim, Ekonomi..., h. 103.

8Muhammad Said, Pengantar Filsafat (Bandung: Refika Aditama, 2008), h. 17. 
dapat diartikan sebagai kebiasaan hidup yang lebih baik, baik dilihat secara individu atau kelompok dalam suatu masyarakat. ${ }^{9}$

Etika menurut Kamus Besar Bahasa Indonesia (KBBI) diartikan sebagai ilmu yang mempelajari tentang kebaikan atau keburukan dan juga ilmu tentang hak ataupun kewajiban moral (akhlak). Jika dilihat dari kedua makna yang berasal dari kamus, maka etika memiliki korelasi kuat dengan "moral", etika dan moralitas memiliki kesamaan makna yaitu sebagai sebagai sistem nilai manusia yang menjadi institusional untuk mengatur manusia agar menjadi lebih baik dan menjadikan kebiasaan yang terus dilakukan berulang kali dan berkelanjutan dalam jangka lama. ${ }^{10}$

Berdasarkan pengertian di atas dapat dipahami bahwa etika memiliki korelasi dengan moralitas, tidak melakukan keburukan dengan memegang nilai maupun norma yang menjadi tuntutan manusia agar menuju kehidupan yang lebih baik. Dalam Islam, etika sebagai disiplin ilmu yang mempelajari tentang kebiasaan seorang muslim yang mencerminkan akhlak dalam setiap perilaku termasuk dalam kegiatan bisnis.

Bisnis memiliki dua pengertian pokok, pertama, bisnis merupakan kegiatan. Kedua, bisnis merupakan sebuah perusahaan. Secara etimologi, bisnis yaitu kegiatan pertukaran antara barang, jasa, ataupun dengan uang yang memberi keuntungan dan memberikan manfaat antara kedua belah pihak yang melakukan pertukaran. ${ }^{11}$ Raymond E. Gols menilai bahwa bisnis memiliki makna luas, bisnis sebagai rangkaian kegiatan dari setiap orang-orang yang diorganisasikan sehingga tehubung dalam kegiatan berniaga ataupun industri untuk memenuhi permintaan kebutuhan manusia dalam bentuk barang ataupun jasa yang memiliki tujuan akhir untuk meningkatkan kualitas dan membenahi kualitas kehidupan manusia. ${ }^{12}$

Mempelajari etika bisnis sama saja halnya mempelajari proses atau upaya untuk mengetahui mana yang buruk dan salah yang berhubungan dengan produk maupun pelayanan dengan pihak yang melakukan pertukuran dengan ketentuan perusahaan. ${ }^{13}$ Hal ini berkonsentrasi pada standar perilaku bisnis, etika bisnis sebagai suatu sistem yang digunakan agar menjadi standar yang diterapkan dalam pelaksanaan produksi yang dilakukan oleh masyarakat untuk menghasilkan barang maupun jasa di dalam perusahaan.

Pada pengertian di atas dapat dipahami bahwa bisnis sebagai kegiatan tukar menukar barang ataupun jasa yang dilaksanakan oleh mansuia secara individu ataupun, kelompok yang mengajarkan manusia untuk kerjasama dengan memperoleh keuntungan sebanyak-banyaknya dengan mengutamakan moralitas dalam melakukan sebuah transaksi, berperilaku, dan berelasi agar bisnis yang dilaksanakan bertujuan selamat.

${ }^{9}$ Agus Arijanto, Etika Bisnis Bagi Pelaku Bisnis (Depok: Raja Grafindo Persada, 2014), h. 5.

10Ibid.,

11Johan Arifin, Etika Bisnis Islami (Semarang: Walisongo Press, 2009), h. 20.

12Husein Umar, Business an Introduction: Definisi Bisnis Menurut Para Ahli (Jakarta: Gramedia Pustaka Utama, 2003), h. 3.

${ }^{13}$ Abdul Azizi, Etika Bisnis Dalam Perspektif Islam (Bandung: Alfabeta, 2013), h. 35. 


\section{C.2. Produksi}

Secara terminologi, ada beberapa pendapat para ekonom muslim sejak zaman klasik hingga kontemporer, diantaranya:

Al-Ghazali ${ }^{14}$ dalam pandangannya jika seseorang berkecimpung di dunia usaha dan memproduksi barang yang jumlahnya cukup untuk kebutuhan masyaraka, maka kewajiban seluruh masyarakat trerpenuhi. Apabila tidak ada seorangpun yang terlibat di dalam dunia usaha dan tidak memproduksi untuk mencukupi kebutuhan manusia, maka semua orang memiliki beban tanggung jawab kelak. Aktifitas ekonomi harus dilakukan seefisen mungkin untuk memenuhi kebutuhan manusia.

Ibnu Khaldun ${ }^{15}$ pandangannya mengenai produksi yakni, sebagai pencurahan tenaga untuk memproduksi sesuatu sesuai dengan kebutuhan, baik kebutuhan individu ataupun kebutuhan masyarakat.

Muhammad Baqir Al-Sadr ${ }^{16}$ menjelaskan bahwa produksi bisa dimaknai yaitu sebuah tata cara pengelolaan sumber daya yang nantinya akan menghasilkan barang ataupun jasa yang bertujuan sebagai jalan menuju kebutuhan manusia.

Abdul Mannan ${ }^{17}$ pandangannya bahwa produksi tidak berorientasi penciptaan secara fisik, melainkan penambahan utilitas terhadap suatu barang. Produksi merupakan bentuk usaha kolektif antar individu masyarakat guna menciptakan barang ataupun jasa yang akhirnya akan mencapai kesejahteraan dalam hal perekonomian. ${ }^{18}$

Kahf ${ }^{19}$ dalam pandangannya bahwa produksi sebagai bentuk usaha manusia agar terus melakukan perbaikan bukan sekadar perbaikan fisik lebih dari itu pada perbaikan moralitas, bentuk upaya untuk menuju tujuan hidup yang telah ditentukan Agama Islam, yaitu tujuan kebahagiaan baik dunia akhirat.

Berdasarkan pemaparan pendapat para ekonom muslim di bagian atas, dapat diartikan bahwa produksi merupakan proses pencapaian suatu barang atau jasa agar memiliki utilitas lebih guna memenuhi kebutuhan masyarakat dengan mengutamakan nilai keadilan dan kemaslahatan.

\section{C.3. Faktor-faktor Produksi}

Kegiatan produksi memerlukan beberapa syarat fundamental agar terciptanya barang ataupun jasa, produksi memerlukan faktor-faktor yang memungkinkan untuk dilakukan produksi. ${ }^{20}$ Faktor-faktor produksi bertujuan

14Al-Ghazali, Ihya' Ulumuddin, terj. Ibnu Ibrahim Ba'adillah (Jakarta: Republika, 2011), h. 123

${ }_{15}$ Abdurrahman Ibnu Khaldun, Muqaddimah Ibn Khaldun (Beirut: Dar al-Fikr, n.d.), h. 380.

16Muhammad Baqir Ash Shadr,Iqtishaduna..., h. 643.

${ }^{17}$ Abdul Mannan, Islamic Economics; Theory and Practice (Pakistan: Ashraf, 1983), h. 85.

${ }_{18}^{8}$ Abdul Mannan, The Frontier of Islamic Economics (AnnArbor: Idarah-I Adabiyat-I Delli, 1984), h. 90.

${ }^{19}$ Monzer Kahf, Ekonomi Islam Telaah Analitik Terhadap Fungsi Ekonomi Islam (Yogyakarta: Aditya, 2000), h. 41.

20Sri Wahyuni, "Teori Konsumsi Dan Produksi Dalam Perspektif Ekonomi Islam," Akuntabel, Vol. 10, No. 1 (Maret2013), h. 77. 
untuk menghasilkan barang atau jasa, produsen harus mampu mengetahui jenis atau macam-macam faktor produksi untuk dapat menghasilkan suatu produk. ${ }^{21}$

\section{Sumber Daya Alam}

Alam merupakan bagian dari faktor produksi yang dimanfaatkan kehadirannya, baik apa yang ada dipermukaan bumi ataupun yang terkandung dalam bumi. Penekanan pada penggunaan sumber daya alam ditunjukkan oleh Rasulullah SAW dalam penggunaan tanah-tanah mati (ihya' Alnawat) sebagai sumber daya untuk kemakmuran rakyat.22 Alam di dalamnya memiliki kekayaan yang banyak sekali yang dapat dimanfaatkan oleh manusia. ${ }^{23}$ Islam mengakui nilai keadilan dengan adanya hak kepemilikan sumber daya yang ada di bumi dengan syarat memanfaatkan juga merawat apa yang ada di bumi yang menjadi salah satu faktor produksi yang bertujuan mendorong manusia untuk mengelola tanah (bagian sumber daya alam) dengan cara yang baik, memanfaatkan alam harus memperhatikan nilai kebutuhan dengan tidak memanfaatkan secara berlebihan dan harus menyeimbangkan pemanfaatannya untuk generasi yang akan datang. ${ }^{24}$

\section{Tenaga Kerja}

Faktor produksi ini merupakan bagian yang penentu nilai kualitas dan kuantitasterciptanya produksi, dapat diartikan bahwa tenaga kerja merupakan kunci pangkal produktivitas dari faktor produksi secara keseluruhan, jika tidak terpenuhinya faktor produksi ini akan berdampak pada tidak terciptanya produk. ${ }^{25}$ Sifat faktor produksi dalam pandangan islam, hubungan antara buruh dengan majikan tidak terlepas dari unsur moral dan sosial. ${ }^{26}$ Hal ini dapat dilihat dari perilaku buruh dengan majikan, dalam memberikan tanggung jawab, proses menjalankan tugas, juga memberi hak upah pekerja, semuanya diberikan sesuai dengan produktivitas kerja.

\section{Modal}

Islam dalam melihat modal memiliki syarat khusus yakni bebasnya modal dari bunga, karena modal sebagai bagian produksi yang mampu menghasilkan, bukan faktor produksi yang pokok. Artinya, modal digunakan untuk mendapatkan tanah, tenaga kerja, atau kebutuhan produksi lainnya.27Islam mengatur modal dengan adil, melindungi kepentingan orang miskin dengan tidak membenarkan modal yang menumpuk pada sebagian orang kaya saja. Keadilan itu terlihat dari Islam

21Suherman Rosyidi, Pengantar Teori Ekonomi Pendekatan Pada Teori Ekonomi Mikro Dan Makro (Jakarta: Raja Grafindo Persada, 2006), h. 55.

22Ika dan Abdul Kadir Riyadi Fauzia, Prinsip Dasar Ekonomi Islam Perspektif Maqosyid AlSyariah (Yogyakarta: Kencana, 2014), h. 118.

23Ilfi Nur Diana, Ekonomi Islam (Jakarta: Rajawali Pers, 2008), h. 43.

${ }^{24}$ Rozalinda, Ekonomi Islam (Jakarta: Rajawali Pers, 2015), h. 116.

25Ika Fauzia dan Abdul Kadir Riyadi, Prinsip..., h. 120.

26Rozalinda, Ekonomi..., h. 115.

27Suherman R, Sistem Ekonomi Islam (Jakarta: Kencana, 2012), h. 201. 
mengatur modal dengan cara mengeluarkan zakat, bekerja sama dengan akad mudharabah, ${ }^{28}$ ataupun musyarakah. ${ }^{29}$

\section{Kecakapan Tata Laksana (Manajemen)}

Kecakapan (skill) merupakan faktor produksi yang krusial. Karena manajer adalah seorang spesialis dalam organisasi yang mengorganisir, merencanakan, mengelola, serta mengordinasi faktor-faktor produksi di atas. $^{30}$ Dalam Islam, menghimbau dalam manajemen mengharuskan memperhatikan keadilan dan tidak berbuat yang merugikan atau membahayakan masyarakat, atas dasar ini Islam melarang untuk melakukan kegiatan mengatur produksi barang-barang haram bahkan merencanakan produksipun tidak diperbolehkan.

\section{C.4. Prinsip Produksi}

Produksi memiliki peranan yang krusial sebagai standar kehidupan manusia juga kesejahteraan pada bangsa. Al-Qur'an memiliki standar yang mengatur dalam produksi, ${ }^{31}$ sebagai mana firman-Nya dalam QS. Al-Qashash ayat 73 yang artinya:

"...Supaya kamu mencari karunia Allah, mudah-mudahan kamu bersyukur," (QS ALQashash [28]: 73) 32

Ayat ini menunjukkan, bahwa terciptanya siang dan malam bertujuan agar manusia berusaha mencari rahmat Allah SWT. Untuk mendapatkan rahmat Allah SWT maka manusia diperintahkan untuk bekerja dengan akal guna mendapatkan kesejahteraan dalam hidup. Dapat disimpulkan produksi adalah prinsip utama dalam ekonomi Islam. Produksi merupakan gambaran yang muaranya ada pada eksistensi manusia, kesejahteraan yang memilki nilai kemaslahatan juga keadilan bagi manusia. Dapat diartikan, kepentingan manusia dan moral islam merupakan prioritas yang harus dijaga dari kegiatan produksi. ${ }^{33}$

Prinsip dasar yang utama dalam proses produksi adalah terciptanya kesejahteraan ekonomi. Dalam islam menilai kesejahteraan ekonomi dengan pandangan yang sangat luas, bahwa kesejahteraan secara umum itu dilihat dari persoalan moral, agama, dan juga pendidikan. Kesejahteraan dalam pandangan islam tidak bermakna bertambahnya pendapatan yang diukur dengan

${ }^{28}$ Murabahah adalah transaksi jual beli antara pemilik objek jual beli dengan pembeli seraya memberikan pengganti setara pada harga pokok disertai penambahan pendapatan atau laba sesuai kesepakatan oleh pemilik objek jual beli dengan pembeli, setelah sebelumnya pemilik objek jual beli menyebutkan harga pokok atas barang tersebut dan menyebutkan juga keuntungan atau laba yang diperoleh pemilik objek.

${ }^{29}$ Musyarakah adalah transaksi kerjasama antara dua atau lebih orang yang melakukan usaha tertentu, kedua pihak memiliki ketentuan yang disepakati pada penentuan akad, kedua belah pihak bisa kemungkinan lebih untuk suatu usaha tertenu. Kedua belah pihak bisa melakukan kerjasama dengan memberikan kontribusi modal dan satu pihak sebagai pekerja, dengan kesepakatan awal keuntungan dibagi sesuai presentase kesepakatan.

30Suherman R, Sistem..., h. 207.

${ }^{31}$ Rozalinda, Ekonomi..., h. 111. h. 315 .

32Departemen Agama RI, Al-Qur'an Dan Terjemahnya (Bandung: Penerbit Dionegoro, 2005),

33Ibid., h. 112. 
bertambahnya finansial, tetapi yang lebih utama dapat memaksimalkan pemenuhan kebutuhan mausia dengan tetap menjaga etika produksi. ${ }^{34}$

\section{C.5. Tujuan Produksi}

Penilaian yang sangat penting pada tujuan produksi dalam perspektif Khalifah Umar RA, pandangannya bahwa: ${ }^{35}$

1. Merealisasikan keuntungan optimal, artinya Umar berpesan kepada seluruh pedagang pada waktu itu untuk beralih dari aktivitas yang tidak merealisasikan keuntungan. ${ }^{36}$

2. Menciptakan kecukupan pribadi maupun keluarga, ${ }^{37}$ artinya setiap orang muslim menjadi kewajiban untuk melakukan kegiatan agar terciptanya kecukupannnya serta mencukupi orang yang menjadi kewajiban atas dirinya. 38

3. Tidak boleh bergantung dengan orang lain, artinya setiap orang muslim yang dinilai mampu untuk bekerja meletakan tangannya di bawah, dan memerintakan pada orang muslim agar berusaha atas kemampuan dirinya. 39

4. Menjaga harta dan memanfaatkan, dalam ekonomi harta memiliki peran agar terciptanya kegiatan perekonomian, dengan harta maka dunia dan agama dapat disyiarkan. Kehadiran harta mampu mendatangkan keistiqomahan dalam menjalankan agama dana mendatangkan ketenangan dalam hidup. Karenanya, di dunia harta merupakan kemuliaan dan kehormatan serta lebih menjadi perantara untuk melindungi agama setiap orang. ${ }^{40}$

5. Mengekspolrasi sumber-sumber ekonomoi dan memanfaatkannya, ${ }^{41}$ artinya manusia haruslah mengekplorasi dunia ini agar mampu memenuhi kebutuhan hidupnya, Allah SWT telah mempersiapkan banyak sumber perekonomian manusia di dunia.

6. Melepaskan dari lingkaran yang bergantung pada ekonomi, ${ }^{42}$ produksi bagian penting untuk mewujudkan kemampuan kemandirian di bidang ekonomi. Kemandirian suatu bangsa dalam mencukupi kebutuhan masyarakat merupakan cerminan bangsa yang tidak bergantungan dengan bangsa lain, atinya mampu menciptakan kesejahteraan yang berdiri di kaki sendiri.

7. Taqarrub atas Allah SWT, ${ }^{43}$ artinya setiap orang muslim yang melakukan proses produksi maka mendapatkan ganjaran pahala dari Allah SWT atas usahanya dalam penciptaan produksi yang bertujuan mendapatkan

\footnotetext{
${ }^{34}$ MA Mannan, Islamic Economic Theory and Practice A Comparative Study (India: Idarah AlAdabiyah, 1988), h. 85.

35Jaribah Bin Ahmad Al-Haritsi, Fikih Ekonomi Umar Bin Al-Khatab (Jakarta: Pustaka AlKautsar, 2014), h. 41.

36Lukman Hakim, Prinsip-Prinsip Ekonomi Islam (Jakarta: Penerbit Erlangga, 2012), h. 69.

37Jaribah Bin Ahmad Al-Haritsi, Fikih..., h. 42.

${ }^{38}$ Lukman Hakim, Prinsip..., h. 69.

39Ibid.,

${ }^{40}$ Ibid.,

41Jaribah Bin Ahmad Al-Haritsi, Fikih..., h. 43.

42Ibid., h. 44.

43Lukman Hakim, Prinsip..., h. 69.
} 
keuntungan dan tujuan lainnya selama aktivitas yang dilakukan seamtamata untuk beribadah kepada Allah SWT.

Produksi dalam perspektif islam semata-mata hanya untuk memenuhi kebutuhan individu, masyarakat, keperluan masa depan, dan pelayanan terhadap masyarakat dengan tingkat kewajaran, serta bertindak adil dan membawa kebajikan bagi orang lain dalam kegiatan produksi.

\section{C.6. Konsep Maqasid Syariah}

Maqasid syariah berasal dari dua kosa kata yaitu al-maqasid dan al-syariah. Al-maqasid merupakan bentuk jamak yang asal kata al-maqsad yang bermakna sebagai arah dan tujuan. ${ }^{44}$ Maqasid berasal dari akar bahasa qasada, yaqsidu, qasidun, yang memiliki arti keinginan kuat, berpegang teguh, dan sengaja. ${ }^{45}$ Secara etimologi, syariah memiliki makna jalan menuju mata air, syariah merupakan asal kata syara'a, yasyri'u, syar'an, diartikan sebagai dimulainya pelaksanaan dalam bekerja. ${ }^{46}$ Secara terminologi syariah yaitu al-mushush almuqaddasah yakni nash yang suci yang berasal dari al-Qur'an dan hadits yang maknanya belum tercampur dari pemikiran manusia, memiliki makna aqidah, amaliyyah, dan khuluqiyyah. ${ }^{47}$

Dari pengertian secara etimologi di atas, maka dapat membantu menjelaskan pengertian maqasid syariah, yakni pembuat syariah Allah SWT dan Rasul-Nya dalam perumusan syariat dan hukum dengan tujuan agar terealisasikan nilai dan makna. ${ }^{48}$ Dalam pandangan Abu Ishaq al-Syatibi maqasid syariah dikembang secara luas dan sistematis, dalam ungkapannya sesungguhnya Syari' pembuat hukum yaitu Allah SWT menetapkan hukum bertujuan untuk kemaslahatan hamba-hambaNya untuk kehidupan masa sekarang dan masa depan. ${ }^{49}$

Berdasarkan pengertian di atas, dapat dipahami baik secara etimologi maupun terminologi bahwa maqasid syariah berkaitan dengan tujuan Allah SWT yang memiliki tujuan kemaslahatan umat manusia hal ini terkanndung dalam menetapkan suatu hukum.

Abu Ishaq al-Syatibi membagi maqasid terbagi menjadi dua macam, yakni maqasid ashliyyahtujuan-tujuan hukum yang kembali kepada tujuan yang dimaksud oleh syari' (Tuhan), tujuan yang mensyari'atkan hukumNya untuk melindungi bagi kemaslahatan manusia saat ini ataupun diakhirat nanti yang pelaksanaannya berpegang teguh pada sumber utama (Al-Qur'an dan Hadits). Artinya tidak ada ruang bagi keterlibatan manusia (mukallaf) sedikitpun, karena ini merupakan hal yang tetap bagi semua agama secara mutlak dan mempunyai untuk patuh dan taat terhadap hukum tersebut. ${ }^{50}$ Maqasid tabi'ah yaitu ketentuan

${ }^{44}$ Abdullah, Alaqah Maqasid Al-Syari'ah Bi Ushul (London: Markaz Dirasad Maqasid alSyariah, 2006), h. 13.

45Ahsan Lihasana, Al-Figh Al-Maqasid Inda Al-Imami Al-Syatibi (Mesir: Dar al-Salam, 2008), h. 11.

46Hasbi Umar, Nalar Fiqih Kontemporer (Jakarta: gaung Persada, 2007), h. 36.

${ }^{47}$ Asafri Jaya Bakri, Konsep Maqasid Al-Syariah Menurut Al-Shatibi (Jakarta: Raja Grafindo Persada, 1996), h. 61.

48Jaser Auda, Figh Al-Maqasid Inatat Al-Ahkam Bi Maqasidiha (Herndon: IIIT, 2007), h. 15.

${ }^{49} \mathrm{Abu}$ Ishaq al-Syatibi, Al-Muwafaqad Fi Ushulal-Syariah (Beirut: Dar al-kutub al-Ilmiyah, 2003), h. 6.

50Wael B Hallaq, Sejarah Teori Hukum Islam Pengantar Untuk Ushul Figh Mazhab Sunni, terj. E. Kusnadiningrat dan Abdul Haris bin Wahid (Jakarta: Raja Grafindo Persada, 2000), h. 267. 
hukum yang di dalamnya ada keterlibatan manusia, maka hal ini dapat mewujudkan keinginan manusia yangbersifat kebutuhan. Maqasid tabi'ah sebagai pelengkap untuk maqasid ashliyyah. 51

Dalam rangka mewujudkan kemaslahatan manusia merupakan tujuan akhir, maka dengan itu kemaslahatan tersebut dapat tercipta dengan memelihara seluruh unsur pokok yaitu, memelihara agama (hifdzu ad-dien), jiwa (hifdzu annafs), akal (hifdzu al-aql), keturunan (hifdzu an-nasl), dan harta (hifdzu al-maal). Dalam kerangka ini, Abu Ishaq al-Syatibi membagi maqasid menjadi tiga tingkatan, yakni:52

Dharuriyat,merupakan maqasid yang tingkat kebutuhannya harus terpenuhi atau bisa disebut sebagai kebutuhan yang utama. Apabila dalam hal ini kebutuhannya tidak bisa tercukupi, maka tidak akan tercipta kesejahteraan yang dapat dirasakan oleh manusia baik untuk saat ini maupun di akhirat kelak, yang mencakup pemeliharaan lima unsur pokok dalam kehidupan manusia, agama, jiwa, akal, keturunan, dan harta. ${ }^{53}$

Hajiyyat, ialah kebutuhan kedua (setelah kebutuhan utama terpenuhi), apabila dalam hal ini kebutuhan tidak terealisasi maka tidak berdampak secara langsung pada keselamatan manusia, tetapi mendatangkan kesulitan. Adanya rukhsah (ringan) sebagai hukum yang digunakan untuk mengurangi beban terhadap kebutuhan ini, adanya kehadiran syariat Islam untun mengurangi kesulitan ini. ${ }^{54}$

Tahsiniyat, kebutuhan ini apabila tidak terpenuhi tidak mengancam eksistensi salah satu dari lima unsur pokok dan tidak pula menimbulkan kesulitan, maqasid ini tingkat kebutuhannya hanya sebagai pelengkap lima unsur pokok kehidupan manusia. 55 Sebagai penentuan Allah SWT mensyariatkan ketentuang yang berkaitan pada kebutuhan tahsiniyat yakni, seperti ibadah, muamalat, dsb.

\section{C.6. Penerapan Maqasid Syariah dalam Produksi}

Tujuan akhir dari kegiatan produksi yaitu untuk memenuhi kebutuhan maslahat untuk manusia, kemaslahatan itu dapat terwujud apabila dapat memelihara dan mewujudkan lima unsur pokok,56yakni; agama, jiwa, akal, keturunan, dan harta. Dalam mewujudkan lima unsur pokok kemaslahatan yaitu dengan cara berikut.

\section{Memelihara Agama (Hifdzu Ad-Dien)}

Memelihara agama merupakan tanggung jawab setiap muslim, kewajiban setiap muslim yang menjalankan rukun iman dan rukun Islam sebagai pedoman hidup. Menilai manusia sebenarnya dapat dilihat dari kekuatan memegang teguh nilai-nilai yang ada pada pedoman agamanya, menjalankan pada kegiatan yang telah diatur Allah SWT agar

51Yusuf Qardhawi, Fiqih Maqashid Syariah (Jakarta: Pustaka Al-Kautsar, 2007), h. 12.

52Nur Chamid, Sejarah Pemikiran Ekonomi Islam (Yogyakarta: Pustaka Pelajar, 2010), h. 280.

53Satria dan M. Zein Efendi, Ushul Fiqh (Jakarta: Kencana, 2005), h. 234.

54Yusuf Al-Qardhawi, Fiqih Praktis Bagi Kehidupan Modern (Kairo: Makabah Wabah, 1999), h.

79.

${ }^{55}$ Adhiwarman .A. Karim, Sejarah Pemikiran Ekonomi Islam (Jakarta: Raja Grafindo Persada, 2004), h. 281.

56Asafri Jaya Bakri, Konsep..., h. 71. 
mendatangkan manfaat yang baik. Banyaknya manusia yang tidak pernah puas dengan hasilnya yang halal, maka banyak sekali manusia yang memenuhi kebutuhan hidup dengan jalan yang bathil sehingga melanggar pedoman hidupnya. Penerapan agama dalam aktifitas produksi yakni larangan melakukan aktifitas produksi yang telah diatur dalam Al-Qur'an, tidak mengambil keuntungan dari alam dengan berlebihan yang akan menyebabkan eksploitasi sehingga mendatangkan kerusakan, kehancuran, dan polusi yang mengakibatkan kerusakan materi, pencemaran alam, melakukan konsumsi dengan tidak membersamai dengan menyebut nama Allah, dengan menganggap konsumsi adalah kegiatan profan, sebab dianggap konsumsi tidak bertalian dengan Allah dan bukan ritual peribadatan.

\section{Memelihara Jiwa atau Diri (Hifdzu An-Nafs)}

Memelihara jiwa yakni menjaga jiwa dan raga agar tetap dapat melakukan aktifitas dengan semata-mata menjalankan roda kehidupan dunia yang kelak akan menghantarkan kehidupan nyata di akhirat nantinya. Pemenuhan kebutuhan manusia harus pada takaran yang jelas, produsen yang menghasilkan barang dan jasa memproduksi sesuai dengan kebutuhan dan bermanfaat bagi manusia dengan tetap menyadari batasan produksi sesuai dengaan kebutuhan saat ini juga diperuntukan bagi kebutuhan pada masa mendatang. Artinya, tidak memproduksi secara berlebihan yang menyebabkan tersisa, baiknya sesuai dengan kebutuhan yang diperlukan. Aktifitas produksi dalam memelihara jiwa dengan memproduksi makanan dan minuman yang tetap mengutamakan kesehatan tubuh dibandingkan dengan nafsu yang tidak memperhatikan kesehatan tubuh, dan dengan bahan dasar yang tidak menggunakan bahan-bahan yang akan menyebabkan kerusakan pada tubuh manusia.

\section{Memelihara Akal (Hifdzu Al-'Aql)}

Agar akal tidak rusak baik secara jiwa dan raga manusia, secara jiwa kerusakan akal bisa bisa menyebabkan datangnya pikiran-pikiran negatif yang merangsang, sedangkan kerusakan raga atau tubuh karena dirusaknya akal yang menyebabkan raga ikut rusak. Aktifitas produksi yang dapat merusak akal diantaranya yakni, memproduksi barang yang tidak sesuai dengan fungsi dan penyimpangan kegunaannya, obat-obatan yang tidak sesuai kegunaannya, minuman keras yang telah beralih kegunaannya, dsb. Kerusakan raga yakni dengan tidak mengeksploitasi raga secara berlebihan dalam setiap aktifitas dengan tetap memperhatikan kebutuhan dan hak raga, serta tidak memberikan konsumsi akal kepada hal yang negatif yang bisa menyebabkan akan berbuat kepada hal yang dilarang oleh agama.

\section{Memelihara Keturunan (Hifdzu An-Nasl)}

Memelihara keturunan yakni menjaga keberlangsungan kehidupan di dunia, dalam pandangan Islam kehidupan bukan sekadar kehidupan dunia tetapi kehidupan nyata ada di akhirat kelak, tetapi keberlangsungan kehidupan dunia harus diperhatikan juga guna menjaga keberlangsungan dan keberlanjutan generasi selanjutnya dengan tetap menjaga alam sebaik mungkin. Aktifitas produksi yang memelihara keturunan dalam 
mengelola sumber daya alam dengan tidak berlebihan dengan memegang teguh prinsip bahwa kebutuhan yang diperlukan manusia memiliki batas sedangkan hawa nafsu manusia yang berlebihan, sehingga memproduksi barang atau jasa tidak berlebihan yang bisa menyebabkan mereduksi kualitas alam dan merusak tatanan rantai makanan. Produksi bukan sekadar memenuhi kebutuhan untuk hari ini, tetap manusia dituntut untuk memproduksi dengan proaktif secara dinamis agar bermanfaat dimasa yang akan datang dalam memenuhi kebutuhan manusia.

\section{Memelihara Harta (Hifdzu Al-Maal)}

Memutar harta agar tetap produktif agar harta tidak mengendap dan rusak yang bisa menyebabkan perputaran uang lambat dan dapat mengganggu stabilitas roda perekonomian. Harta material menjadi syarat fundamental untuk keberlangsungan kehidupan dunia dan akhirat dalam memenuhi kebutuhan jiwa dan raga manusia, jiwa dengan cara berzakat, bersedekah kepada orang yang membutuhkan, sedangkan raga dengan cara memenuhi kebutuhan primer (pangan, sandang, papan), sekunder, dan tersier untuk menjaga keberlangsungan hidup. Harta harus terus dikembangkan agar terjadi perputaran perekonomian, semakin cepat perputaran uang maka semakin tumbuh perkeonomian di daerah tersebut, begitu juga sebaliknya. Islam melarang setiap orang menyimpan hartanya dan tidak menafkahinya di jalan Allah, serta memberi ganjaran siksaan bagi setiap orang yang tidak mengindahkan ketentuanNya.

\section{Simpulan}

Islam telah mengatur produksi dengan memperhatikan nilai-nilai keadilan, produksi merupakan kegiatan yang menghasilkan barang atau jasa sesuai dengan faktor-faktor produksi yang dimiliki. Kegiatan produksi tanpa dilandasi dengan etika bisnis maka hanya menghasilkan barang atau jasa yang hanya berorientasi pada pemenuhan kebutuhan saja, dengan etika produksi maka akan menjaga nilai keadilan dan moralitas sebagai sarana batasan menuju fallah (kesejahteraan). Dharuriyat,merupakan maqasid yang tingkat kebutuhannya harus ada atau disebut juga kebutuhan primer. Jika tingkat kebutuhan ini tidak terpenuhi, maka kesejahteraan manusia di dunia dan di akhirat kelak tidak akan terealisasi, kegiatan produksi dalam rangka mewujudkan kemaslahatan manusia, kemaslahatan itu dapat terwujud apabila dapat memelihara dan mewujudkan lima unsur pokok, yakni; agama, jiwa, akal, keturunan, dan harta.

\section{Referensi:}

Abdullah. 2006. Alaqah Maqasid Al-Syari'ah Bi Ushul. Markaz Dirasad Maqasid alSyariah, London.

Agama RI, Departemen. 2005. Al-Qur'an Dan Terjemahnya.Penerbit Dionegoro, Bandung.

Al-Ghazali. 2011.Ihya' Ulumuddin. Republika, Jakarta.

Al-Haritsi, Jaribah Bin Ahmad. 2014. Fikih Ekonomi Umar Bin Al-Khatab. Pustaka Al-Kautsar, Jakarta.

Al-Qardhawi, Yusuf. 1999.Fiqih Praktis Bagi Kehidupan Modern.Makabah Wabah, Kairo. 
al-Syatibi, Abu Ishaq. 2003. Al-Muwafaqad Fi Ushulal-Syariah.Dar al-kutub alIlmiyah, Beirut.

Arifin, Johan. 2009. Etika Bisnis Islami. Walisongo Press, Semarang.

Arijanto, Agus. 2014. Etika Bisnis Bagi Pelaku Bisnis.Raja Grafindo Persada, Depok. Asafri Jaya Bakri. 1996.Konsep Maqasid Al-Syariah Menurut Al-Shatibi. Raja Grafindo Persada, Jakarta.

Auda, Jaser. 2007. Fiqh Al-Maqasid Inatat Al-Ahkam Bi Maqasidiha. IIIT, Herndon.

Azizi, Abdul. 2013Etika Bisnis Dalam Perspektif Islam.Alfabeta, Bandung.

Chamid, Nur. 2010. Sejarah Pemikiran Ekonomi Islam. Pustaka Pelajar, Yogyakarta.

Diana, Ilfi Nur. 2008.Ekonomi Islam. Rajawali Pers, Jakarta.

Efendi, Satria dan M. Zein. 2005. Ushul Figh. Kencana, Jakarta.

Fauzia, Ika dan Abdul Kadir Riyadi. 2014.Prinsip Dasar Ekonomi Islam Perspektif Maqosyid Al-Syariah. Kencana, Yogyakarta.

Hakim, Lukman. 2012.Prinsip-Prinsip Ekonomi Islam. Penerbit Erlangga, Jakarta.

Hallaq, Wael B. 2000. Sejarah Teori Hukum Islam Pengantar Untuk Ushul Figh Mazhab Sunni. Raja Grafindo Persada, Jakarta.

Kahf, Monzer. 2000.Ekonomi Islam Telaah Analitik Terhadap Fungsi Ekonomi Islam. Aditya, Yogyakarta.

Karim, Adhiwarman .A. 2007.Ekonomi Mikro Islami.Raja Grafindo Persada, Jakarta.

- - - . 2004.Sejarah Pemikiran Ekonomi Islam. Raja Grafindo Persada, Jakarta.

Khaldun, Abdurrahman Ibnu. n.d.Muqaddimah Ibn Khaldun. Dar al-Fikr, Beirut.

Lihasana, Ahsan. 2008.Al-Fiqh Al-Maqasid Inda Al-Imami Al-Syatibi.Dar al-Salam, Mesir.

Mannan, Abdul. 1983.Islamic Economics; Theory and Practice. Ashraf, Pakistan.

- - - 1984. The Frontier of Islamic Economics. Idarah-I Adabiyat-I Delli, AnnArbor.

Mannan, MA. 1988. Islamic Economic Theory and Practice A Comparative Study.Idarah Al-Adabiyah, India.

Qardhawi, Yusuf. 2007. Fiqih Maqashid Syariah. Pustaka Al-Kautsar, Jakarta.

R, Suherman. 2012.Sistem Ekonomi Islam. Kencana, Jakarta.

Rosyidi, Suherman. 2006. Pengantar Teori Ekonomi Pendekatan Pada Teori Ekonomi Mikro Dan Makro. Raja Grafindo Persada, Jakarta.

Rozalinda. 2015.Ekonomi Islam. Rajawali Pers, Jakarta.

Said, Muhammad. 2008. Pengantar Filsafat.Refika Aditama, Bandung.

Shadr, Muhammad Baqir Ash. 2008.Buku Induk Ekonomi Islam: Iqtishaduna. Vol. 1.Zahra, jakarta.

UII, Pusat Pengkajian dan Pengembangan Ekonomi Islam (P3EI). 2008Ekonomi Islam. RajaGrafindo Persada, Jakarta.

Ulum, Fahrur. 2009. “Telaah Kritis Atas Pemikiran Ekonomi Islam Abdul Mannan." al-Qanun. 448.

Umar, Hasbi. 2007.Nalar Fiqih Kontemporer. gaung Persada, Jakarta.

Umar, Husein. 2003. Business an Introduction: Definisi Bisnis Menurut Para Ahli. Gramedia Pustaka Utama, Jakarta.

Wahyuni, Sri. 2013. “Teori Konsumsi Dan Produksi Dalam Perspektif Ekonomi Islam." Akuntabel. 77.

Yuniarti, Vina Sri. 2016.Ekonomi Mikro Syariah. Pustaka Setia, Bandung. 